BIOMEDICAL AND BIOSOCIAL ANTHROPOLOGY
$\begin{gathered}\text { Official Journal of the International Academy } \\ \text { of Integrative Anthropology } \\ \text { journal homepage: htp://bba-journal.com }\end{gathered}$

\title{
Determination of individual cephalometric characteristics of the occlusal plane in Ukrainian young men and young women with orthognatic bite
}

Dmitriev M. 0.1, Gunas I. V. ${ }^{1}$, Dzevulska I. V. ${ }^{2}$, Zhulkevych I. V. ${ }^{3}$

${ }^{1}$ National Pirogov Memorial Medical University, Vinnytsya, Ukraine

${ }^{2}$ Bogomolets National Medical University, Kyiv, Ukraine

${ }^{3}$ I. Horbachevsky Ternopil State Medical University, Ternopil, Ukraine

\section{ARTICLE INFO}

Received: 3 September, 2018

Accepted: 31 October, 2018

UDC: $616.716 .8-071-084: 613.956$ :

617.52: $616.34 .25-007.481-7$

\section{CORRESPONDING AUTHOR}

e-mail: dmitriyevnik@gmail.com

Dmitriev M. O.
To date, there are no clear recommendations on the use of a particular indicator, cephalometric method, normative basis for the inhabitants of Ukraine when assessing the cephalometric characteristics of the occlusal plane. The purpose of the study - by studying cephalometric indices and conducting direct stepwise regression analysis develop in young men and women of Ukraine with orthognathic bite mathematical models of individual characteristics of the position of the occlusal plane. In 38 young men (aged 17-21 years) and 55 young women (aged from 16 to 20 years) with occlusion close to orthognathic bite and balanced faces, lateral teleroentgenograms were obtained using the Veraviewepocs 3D device, Morita (Japan). Cephalometric analysis was performed using OnyxCeph ${ }^{3}$ TM software. Cephalometric points and measurements were performed according to the recommendations of $W$. B. Downs, J. McNamara, $R$. A. Holdway, P. F. Schmuth, A. M. Schwarz, C. C. Steiner and C. H. Tweed. In the licensed statistical package "Statistica 6.0", using regression analysis, the following teleroentgenographic characteristics of the position of the occlusal plane were simulated: the angle YGOCLPI, the angle POR_DOP, the angle POR_OCP, and the $S N \_O S P$ angle. It was established that in both young men and women, all four possible models with a determination coefficient from 0.808 to 0.998 in young men and from 0.832 to 0.974 in young women were constructed. In the analysis of models of teleroentgenographic characteristics of the position of the occlusal plane, depending on the peculiarities of the metric characteristics of the craniofacial complex, it was found that in young men the most frequent regression equations include - the Wits indicator (21.1\% for all four equations), the angle AB_NPOG (15.8\%) and the distance $P N \_P O G(10.5 \%)$. In young women, most often the regression equations include - Wits indicator (17.4\% - also to all 4 equations); angle $A B \_N P O G$, distance $A F H$, angle $M M$ and angle SN_GoGn (by 8.7\%). So, using the method of stepwise regression, among Ukrainians of juvenile age, based on the features of teleroentgenographic indicators, reliable models of individual cephalometric characteristics of the occlusal plane were created.

Keywords: occlusal plane, cephalometry, regression analysis, young men and women, orthognathic bite.

\section{Introduction}

The issue of dentitions occlusion in scientific and practical literature have a lot of attention. The existence of different philosophies, techniques, often lack of common definitions - constantly encourages scientists and practitioners to conduct new research in this field. With the development of science, there is more and more issues related to the functioning of the tooth-jaw system and its impact on other organs and systems.

One of the main functions of the teeth and jaws is chewing function, which is implemented when closing the dental rows of the upper and lower jaws. The closure occurs in certain occlusion contact points, the totality of which forms the actual occlusion plane. Depending on the shape and nature of the closure, different contact groups are formed 
and, accordingly, distinguish functional and static occlusion planes, which are usually depicted for technical reasons as straight lines on sagittal and frontal projections. And since the parameters of the occlusion planes are closely related to the characteristics of the teeth, anatomy and the functioning of the temporomandibular joints, the nature of the growth of craniofacial structures and muscle function, it is precisely because of the change in occlusion that we have the possibility of indirect influence on the above structures. A well-known gnathologist, one of the founders of the doctrine of the "chewing organ" Rudolf Slavicek notes: "The functions of the chewing organ are completely different and are closely connected to the somatic and mental functions of the brain. Of course, there is adaptability and compensatory capacity. However, the chewing organ and the psyche are closely interconnected "[30].

Very acute question arises about the creation of artificial occlusion surface in the treatment of complete adentia. So, in the manufacture of complete dentures, it is suggested to use the found dependencies of the location of the occlusion plane in relation to different anatomical planes. As a result of the use of completely non-invasive methods with the use of optical three-dimensional scanning systems and the creation of a three-dimensional object with facial and dental structures, the averaged relation of the occlusion plane and the Camper's plane passing through the tragus and subnasale, and having a $4.9^{\circ}$ inclination in the sagittal plane, was invented [25]. However, research of Quran F. A. M. A., Hazza'a A. and Nahass N. A. [24] argues that the use of a plane that passes through the upper edge of the tragus and the lower edge of the nose wing is more correct for determining the occlusion plane.

The position of the closure planes is investigated in relation to the HIP-plane (Hamulus-Incisive-Papilla), which is quite convenient for clinical use. It is recommended to use the mean values of the angle of inclination of the occlusion plane that passes through the incisal edge of the central incisors and the mesiobuccal cusp of the upper first molar $-2.61 \pm 0.81^{\circ}$ and mesiobuccal cusp of the upper second molar - 7.72 $\pm 1.60^{\circ}$ [14], although works by Jayachandran S., Ramachandran C. R. and Varghese R. [20] point to the parallelism of the planes. V. A. Khvatov [21] indicates exactly the orthopedic plane passing through the distobuccal cusp of second molar and the incisal edge of the central incisor of the mandible parallel to the Camper's horizontal. The author recommends such a plane when installing models in articulator, X-ray analysis, as well as in the analysis of motion recordings.

Determination of the occlusion plane pays great attention not only by maxillofacial surgeons and orthopedists, but also orthodontists. Jack Dale, in a document presented at the Charles H. Tweed Foundation Meeting in 1992, called the occlusion plane "working table of orthodontics" [22]. Understanding the importance of proper control of the occlusion plane is fundamental to the success of clinical treatment.
Since the occlusion surface is rather complicated, it is usually presented as a straight line which combines certain light-weight currents in the sagittal plane to simplify the understanding of skeletal and occlusion ratios on lateral teleroentgenographic images. W. B. Downs [12] used the ADP constructive point (anterior Downs point) the front point of the occlusion plane by Downs - center of the line connecting the incisal edges of the upper jaw and lower jaw central incisors and PDP (posterior Downs point) - the back point of the occlusion plane by Downs - the middle of the line, which connects mesiobuccal cusp of the upper first molar of the upper and lower jaw. C. C. Stainer [31] defined the occlusion plane by passing it through the points apOcP (anterior point of the occlusal plane, the ADP analog, the anterior point of the occlusion plane by Downs) and ppOcP (posterior point of the occlusal plane), the back point of the occlusion plane by Steiner - is located in the place of the most rear contact of the first molars.

Also, the position of the tooth row in the facial skeleton can be characterized by a line passing through the incisal edges of central incisors and distal lobes of second molars, separately for the upper or lower jaw [21, 33].

Fushima K. et al. [15] proposes to consider two occlusion planes - the anterior and posterior. The anterior occlusion plane is a line extending from the incisal edge of the central incisor of the upper jaw to the cusp of the upper second premolar. Posterior occlusion plane - a line extending from the lobe of the upper second premolar and the medial point of the occlusal surface of the upper second molar. This approach allows flexible approach to the diagnosis of toothjaw abnormalities and often puts the main goal of treatment - the normalization of the position of occlusion planes.

Three-dimensional studies by Coro J. C. et al. [5] of 111 people of different sex and age not only confirmed the dependence of the location of the rear occlusion plane in relation to the Frankfurt area in different facial types but also found tight correlations between the inclination of the posterior occlusion plane and the height of the branch and length of the body of the mandible. In addition to the morphological characteristics, closely related to the posterior occlusion plane, the presence and nature of lateral deviations of the mandible were revealed.

Choi Y. J. and co-authors [4] note that, in their studies of a group of treated patients with such a complex treatment plan and the stability of the results of dental implant pathology as the front open the bite, depending on the cephalometric configuration of the occlusion plane, and in particular the nature of the occlusion of premolars, there were different results of treatment.

It should also be noted that ignoring the degree of inclination of the occlusion surface can significantly affect the validity of such key diagnostic teleroentgenographic indicators as ANB angle and WITS indicator [6].

Analysis of the spatial location of the occlusion plane does not have any value in the treatment of functional disorders. So, research by Sato M. et al. [27] demonstrate 
the close correlations of characteristics of chewing movements and muscle work with spatial position of occlusion plane, which allows professionals to work not only within the anatomical standards but also influence the complex functional connection elements craniofacial complex.

To assess the cephalometric characteristics of the occlusion plane in determining the orthodontic diagnosis, teaching aids suggest to use norms $[11,13,16]$ that have been developed for different ethnic populations of other countries. And for today there are no clear recommendations on the use of a particular indicator, one or another cephalometric method, as well as what normative bases, which country or ethnic group should be used for Ukrainian citizens.

The purpose of the study - by studying cephalometric indices and conducting direct stepwise regression analysis to develop in young men and women of Ukraine with orthognathic bite mathematical models of individual characteristics of the position of the occlusion plane.

\section{Materials and methods}

With the use of Veraviewepocs 3D device, Morita (Japan) in 38 young men (17 to 21 years of age) and 55 young women (aged from 16 to 20 years) with occlusion close to the orthognathic and balanced face have received side teleroentgenograms. Cephalometric analysis was performed using OnyxCeph ${ }^{3 \mathrm{TM}}$ software. Cephalometric points and measurements were performed according to the recommendations of A. M. Schwarz, J. McNamara, W. B. Downs, R. A. Holdway, P. F. Schmuth, C. C. Steiner and C. H. Tweed [12, 19, 23, 28, 29, 31, 32]. The analysis of teleroentgenograms and the results of their researches for Ukrainian young men and women is described in detail and set out in a number of previous articles [7-10, 17, 18].

In accordance with the above-mentioned procedures, we simulated the following teleroentgenographic characteristics of the position of occlusion planes (Fig. 1): YGOCLPI - the angle of inclination of the occlusion plane to the palatine plane is formed by the lines Is1L-DPOcl and ANS-PNS $\left({ }^{\circ}\right)$; POR_DOP - angle of inclination of the occlusion plane by Downs to the Frankfurt area, formed by the lines Po-Or and ADP-PDP $\left({ }^{\circ}\right)$; POR_OCP - angle of inclination of the occlusion plane by Steiner to the Frankfurt plane, formed by the lines of apOcP-ppOcP and Po-Or $\left(^{\circ}\right)$; SN_OCP - the angle of inclination of the shutter plane by Steiner to the front of the skull, formed by the lines apOcPppOcP and $\mathrm{S}-\mathrm{N}\left({ }^{\circ}\right)$.

The statistical processing of the obtained results was carried out in the license package "Statistica 6.0" using a direct stepwise regression analysis.

\section{Results}

As a result of modeling teleroentgenographic characteristics of the occlusion plane in young men and women with orthognathic bite and balanced face,

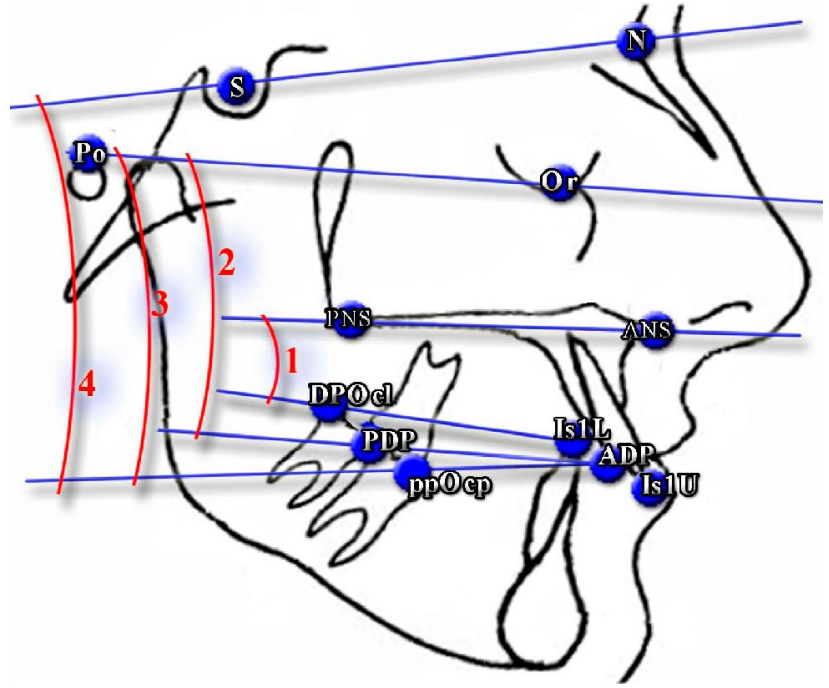

Fig. 1. Teleroentgenographic characteristics of the position of occlusion planes. 1 - YGOCLPI, 2 - POR_DOP, 3 - POR_OCP, 4 SN OCP.

depending on the metric parameters of the skull, we constructed the following linear equations.

For young men:

YGOCLPL $=-33.59-0.224 \times \mathrm{N}$ SP SP $-0.981 \times$ WITS + $0.465 \times \mathrm{T}+0.109 \times \mathrm{GL}$ SN_S $+0.439 \times \mathrm{MM}-0.167 \times$ GL_SNPOG $\left(R^{2}=0.808 ; F_{(6.29)}=20.35 ; p<0.001\right.$; Error of estimate $=1.858)$,

POR_DOP $=10,84-0.483 \times$ PN_POG $-1.396 \times$ WITS $0.778 \times$ AB_NPOG $-0.217 \times \mathrm{AFH}+0.132 \times \mathrm{B}\left(\mathrm{R}^{2}=0.953\right.$; $F_{(5.30)}=122.4 ; p<0.001$; Error of estimate $\left.=1.050\right)$,

POR_OCP $=8.421-0.457 \times$ PN_POG - $1.170 \times$ WITS $0.782 \times A B \_N P O G-0.106 \times R \_A S C\left(R^{2}=0.988 ; F_{(4.31)}=627.6\right.$; $\mathrm{p}<0.001$; Error of estimate $=0.518)$,

SN_OCP $=77.24-0.801 \times$ SND $-1.439 \times$ WITS $-0.916 x$ $A B \_N P O G-0.105 \times S \_L\left(R^{2}=0.980 ; F_{(4.31)}=375.2 ; p<0.001\right.$; Error of estimate $=0.745$ ).

For young women:

YGOCLPL $=-34.59+0.453 \times B-0.551 \times$ FMA $-0.369 \times$ P_OR_N $+0.149 \times$ N_POG_- $1.311 \times$ WITS $+0.749 \times \mathrm{MM}$ $\left(\mathrm{R}^{2}=0 . \overline{8} 32 ; \mathrm{F}_{(6.44)}=36 . \overline{37} ; \mathrm{p}<\overline{0.001}\right.$; Error of estimate=1.769),

POR_DOP $=-54.08-0.483 \times$ PN_POG $+0.292 \times$ SN_GOGN $+0.858 \times \mathrm{F}-0.532 \times \mathrm{SNA}-0.201 \times \mathrm{AFH}+0.342$ $x \mathrm{MM}-0.555 \times$ WITS $\left(R^{2}=0.849 ; F_{(7.43)}=34.52 ; p<0.001\right.$; Error of estimate $=1.954$ ),

POR_OCP $=-39.83+0.891 \times$ POR_GNS $+0.112 \times$ ML_NSL - $0.169 \times$ AFH - $0.638 \times$ AB_NPOG $-0.915 \times$ WITS $\left(R^{2}=0.929 ; F_{(5.45)}=117.2 ; p<0.001\right.$; Error of estimate=1.227), 
SN_OCP $=85.33+0.073 \times$ SN_GOGN $-0.993 \times$ SND + $0.060 \times$ PN_A - $1.424 \times$ WITS $-0.841 \times A B \_N P O G\left(R^{2}=0.974\right.$; $F_{(5.45)}=335.6 ; p<0.001$; Error of estimate $\left.=0.659\right)$.

In the constructed models: $R^{2}$ - coefficient of determination; $F_{(! ! ! !)}=$!!.!! - critical (!!!!) and got (!!!.!!) value of Fisher's criterion; St. Error of estimate - standard error of the standardized regression coefficient; AB_NPOG - angle formed by lines $\underline{A-B}$ and $\underline{N-P o g}$ (defines the position of the plane $\underline{A B}$ in relation to the $\underline{\mathrm{N}-\mathrm{pog}}$ ); $\mathrm{AFH}$ (distance $\mathrm{AFH}$ or front height of the face) - distance from the point $\underline{\mathrm{Me}}$ to the line ANS-PNS; B (basal angle) - formed by lines ANS-PNS (palatine plane $\underline{\mathrm{SpP}}$ ) and $\underline{\mathrm{Im}-\mathrm{Me}}$ (mandibular plane $\underline{\mathrm{MPS}}$ by Schwarz) (indicates the angle between the upper and lower jaws); F (face angle or angle F) - formed by lines Se$\mathrm{N}$ and $\mathrm{N}-\mathrm{A}$ (determines the location of the anterior contour of the upper jaw in the jet plane to the base of the skull); FMA (angle FMA, also meets the designation POr_MeGo) formed by lines tGo-Me (mandibular plane $\underline{\mathrm{Mp}}$ ) and $\underline{\mathrm{Po}-\mathrm{Or}}$ (Frankfurt plane Fp); GL_SN_S (index Gl'Sn_Sn_Gn' or facial vertical index) - distance ratio of $\underline{\mathrm{Gl}}-\mathrm{Sn}$ and $\underline{\mathrm{Sn}-\mathrm{Gn}}$ (defines vertical relationships in the face profile); GL_SNPOG (angle Gl'SnPog' or indicator of convexity of the soft tissue profile) - formed by lines Gl'-Sn and Sn-Pog'; ML_NSL (angle ML_NSL, or angle SN_GoMe) - is formed by lines tGo-Me and $\underline{\mathrm{S}-\mathrm{N}}$ (angle of inclination of the mandibular plane to the base of the skull); MM (maxillomandibular angle) - is formed by lines $\underline{A-B}$ and $\underline{\text { ANS-PNS }}$ (defines the angle below which the upper jaw is located in relation to the lower jaw in the sagittal plane); N_POG_ (angle N'Hold_Pog'_Hline) - angle between lines Ls-Pog' ( $\underline{H}$ line,$H o l d w a y$ line) and N'Hold-Pog'; N_SP_SP (coefficient N_Sp'_Sp'_Me) - distance ratio $\underline{N}$-Sp' and $\underline{S p}$ '$\mathrm{Me}$ (the ratio of the upper and lower height of the face); P_OR_N (soft tissue angle, or angle P_Or_N'Hold_Pog') formed by lines Po-Or and N'Hold-Pog'; PN_A (distance PN_A) - distance from the point $\underline{A}$ to the point $\underline{P N m}$ (perpendicular line from the point $\underline{N}$ to the line $\underline{P o-O r}$ ); PN_POG (distance PN_Pog) - distance from the point Pog to the nose perpendicular $\underline{P N}$ (perpendicular line from the point $\underline{N}$ to the line $\underline{P o-O r}$ ); POR_GNS (angle POr_GnS or $\mathrm{Y}$ axis) - angle formed by lines Po-Or and S-Gn (angle of inclination $\mathrm{Y}$-axis relative to the Frankfurt horizontal); R_ASC (length of the branch of the mandible) - distance from the constructive point R.asc to a constructive point tGoS; S_L (distance S_L or the front length of the skull base by Steiner) - from the point $\underline{S}$ to a constructive point $\underline{L}$, which is formed at the intersection of the perpendicular carried out from the point Pog to the line Se-N; SN_GOGN (angle SN_GoGn) is formed by lines Go-Gn and $\underline{\mathrm{S}-\mathrm{N}}$ (angle of inclination (MpSt) mandibular plane by Stainer, to the base of the skull); SNA (angle SNA) - is formed by lines $\underline{\mathrm{S}-\mathrm{N}}$ and $\underline{\mathrm{N}-\mathrm{A}}$ (indicates the anterior-posterior position of the upper jaw to the base of the skull); SND (angle SND) - formed by lines $\underline{\mathrm{S}-\mathrm{N}}$ and $\mathrm{N}-\mathrm{D}$ (indicates the anterior-posterior location of the symphysis ( $\underline{D}$ - the center of the symphysis ossification) of the lower jaw to the base of the skull); $T$ (profile angle $T$ ) - is

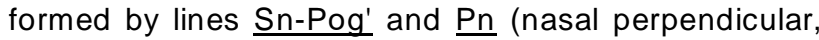
perpendicular to the line from the point $\underline{N^{\prime}}$ to the line $\underline{\text { Se-N}}$ ); WITS (indicator Wits) - distance between constructive points $\underline{\mathrm{AOclP}}$ and BOcIP - projections of the corresponding points $\underline{A}$ and $\underline{B}$ on the line apOcP-ppOcP (OcPSt, closing plane by Steiner), indicates a linear interjaw ratio in the anteriorposterior direction (if the projection of point $\underline{A}$ lies ahead of the projection of point $\underline{B}$ then the indicator takes a positive value; if the projection of point $\underline{A}$ lies behind the projection of point $\underline{B}$ then the indicator takes a negative value).

\section{Discussion}

In addition to the existence of different views on the definition of occlusion plane, discussions and scientific research are constantly under way to find regularities and correct landmarks to determine its spatial position.

Thus, Camara C. A. and Martins R.P. [2] suggested the use of a Functional Aesthetic Occlusal Plane (FAOP), which passes through the point of closure of the lips and the midpoint of the contact between the molars of the upper and lower jaws as a benchmark. It is noted that the maximum functional and aesthetic result is observed at the tangent location of the edge of the lower central incisors to this plane and the location of the incision edge of the maxillary central incisors is $2-4 \mathrm{~mm}$ below the latter.

S. Braun et al. [1] when investigating 260 people found geometric dependencies, in the form of regression polynomials, the distance from the center of the mandibular fossa to the functional occlusion plane and the angle of the latter with respect to the anterior part of the base of the skull, the S-N line.

Investigation by Čelar A. et al. [3] revealed a different nature of the location of occlusion planes, depending on different skeletal types and classes of dental anomalies by Engle. They retrospectively investigated teleroentgenograms of 230 people for the presence of bisectorial, reverse and backplane correlations with the Frankfurt (P-Or) and basal (S-Na) planes. Studies have shown stronger and more stable correlations with the basal plane compared to the Frankfurt, possibly due to the frequent difficulties in the localization of the orbital point and the porion. So in the group with skeletal second class, the anterior and posterior occlusion planes had a steeper (larger) angle of inclination compared with a more horizontal position in people with skeletal third grade. When divided into groups by the nature of the occlusion of the first molar by Engle, the front occlusion plane did not have statistically significant differences in relation to both planes, but at the same time the posterior occlusion plane significantly differed. The group with the first class correlation of molars had the most horizontally located occlusion plane.

Sahoo S. et al. [26] conducted a rather deep analysis of the literature from 1963 to 2013 relating to the determination of the occlusion plane, it is concluded that there are few real long-term studies and reliable data that could 
recommend a single reliable orientation for determining the occlusion plane in various clinical cases.

In young men and women with orthognathic bite we developed reliable models of individual teleroentgenographic characteristics of the position of the occlusion plane, depending on the peculiarities of the metric characteristics of the craniofacial complex. It was established that in both young men and women, all four possible models with a determination coefficient of 0.808 to 0.998 in young men and from 0.832 to 0.974 in young women were constructed.

In the analysis of the models, it was found that in young men most often the regression equations include the Wits index, which indicates the linear interjaw relation in the anterior-posterior direction (21.1\% to all four equations), the angle AB_NPOG (15.8\%), and the distance PN_POG $(10.5 \%)$ In young women, most often the regression equations include - the Wits indicator $(17.4 \%$ - to all 4 equations); angle AB_NPOG, distance AFH (or forward facial height), maxillo-mandibular angle MM and angle SN_GoGn (by $8.7 \%$ ). It should be noted that among the metric characteristics of the craniofacial complex to the models of teleroentgenographic characteristics of the position of the occlusion plane only in young men include the index Gl'_Sn_Sn_Gn ', the angle GI'SnPog', the coefficient $\mathrm{N} \mathrm{Sp}^{\prime} \mathrm{Sp}^{\prime} \mathrm{Me}$, the length of the branch of the mandible $\mathrm{R} \_\mathrm{ASC}$, the distance $\mathrm{S} \_\mathrm{L}$ and the profile angle $\mathrm{T}$, and only

\section{References}

[1] Braun, S., Kim, K., Tomazic, T., \& Legan, H. L. (2000). The relationship of the glenoid fossa to the functional occlusal plane. Am. J. Orthod. Dentofacial. Orthop., 118(6), 658-661. doi: $10.1067 / \bmod .2000 .111224$

[2] C?mara, C. A., \& Martins, R. P. (2016). Functional Aesthetic Occlusal Plane (FAOP). Dental Press Journal of Orthodontics, 21(4), 114-125. doi: https://dx.doi.org/10.1590/21776709.21.4.114-125.sar

[3] Čelar, A., Tafaj, E., Graf, A., \& Lettner, S. (2018). Association of anterior and posterior occlusal planes with different Angle and skeletal classes in permanent dentitions : A lateral cephalometric radiograph study. Journal of Orofacial Orthopedics, 79(4), 267-276. doi: 10.1007/s00056-018-0139z

[4] Choi, Y. J., Kim, D. J., Nam, J., Chung, C. J., \& Kim, K. H. (2016). Cephalometric configuration of the occlusal plane in patients with anterior open bite. American Journal of Orthodontics and Dentofacial Orthopedics, 149(3), 391-400. doi: 10.1016/ j.ajodo.2015.08.020

[5] Coro, J. C., Velasquez, R. L., Coro, I. M., Wheeler, T. T., McGorray, S. P., \& Sato, S. (2016). Relationship of maxillary 3-dimensional posterior occlusal plane to mandibular spatial position and morphology. American Journal of Orthodontics and Dentofacial Orthopedics, 150(1), 140-152. doi: 10.1016/ j.ajodo.2015.12.020

[6] Del Santo, M. (2006). Influence of occlusal plane inclination on ANB and Wits assessments of anteroposterior jaw relationships. American Journal of Orthodontics and Dentofacial Orthopedics, 129(5), 641-648. doi: 10.1016/ j.ajodo.2005.09.025

[7] Dmitriev, M. O. (2016). Definition of normative cephalometric for young women - the angle or angle $F$, the angle FMA, the angle ML_NSL, the angle N'Hold_Pog'_Hline, the angle P_Or_N'Hold_Pog', the distance PN_A, the angle POr_GnS, the angle SN_GoGn and the angle SNA.

Consequently, taking into account the importance of determining the teleroentgenographic parameters of the spatial position of the occlusion plane and the diversity of the proposed methods, as well as the absence of the possibility of identifying individual normative diagnostic values, there is a scientific and clinical interest in conducting research on these issues. And the use of modern mathematical techniques allows us to develop tools for the determination of individual normative values of the position of occlusion planes, taking into account their ethnic, sexual, age and anatomical features of man.

\section{Conclusions}

In young men and women with orthognathic bite, all four possible models of individual teleroentgenographic characteristics of the position of the occlusion plane are constructed, in accordance with the determination coefficients from 0.808 to 0.998 and from 0.832 to 0.974 . In young men models most often included - Wits indicator $(21.1 \%)$, the angle AB_NPOG (15.8\%) and the distance PN_POG (10.5\%), while in young women - the Wits indicator $(17.4 \%)$, the angle AB_NPOG, the distance AFH, the angle MM and angle SN_GoGn (by $8.7 \%$ ).

parameters by Steiner method for Ukrainian young men and women. World of Medicine and Biology, 3(57), 28-32.

[8] Dmitriev, M. O. (2017). Identification of normative cephalometric parameters based on $\mathrm{G}$. Schmuth method for young male and female Ukrainians. Reports of Morphology, 23(2), 288-292.

[9] Dmitriev, M. O. (2018). Determination of standard cephalometric parameters using the Downs method for Ukrainian adolescents. Reports of Morphology, 24(2), 22-26. doi: 10.31393/morphology-journal-2018-24(2)-03

[10] Dmitriev, M. O., Chugu, T. V., Gerasymchuk, V. V., \& Cherkasova, O. V. (2017). Determination of craniometric and gnatometric indicators by A. M. Schvartz metod for Ukrainian boys and girls. Biomedical and Biosocial Anthropology, 29, 53-58.

[11] Doroshenko, S. I., \& Kulginskiy, E. A. (2007). Teleroentgenography Basics. K.: Health.

[12] Downs, W. B. (1956). Analysis of the dentofacial profile. Angle Orthodontist, 26, 191-212.

[13] Flis, P. S. (2007). Orthodontics. Textbook for students of higher medical schools. Vinnitsa: The New Book.

[14] Fu, P. S., Hung, C. C., Hong, J. M., \& Wang, J. C. (2007). Threedimensional analysis of the occlusal plane related to the hamular-incisive-papilla occlusal plane in young adults. Journal of Oral Rehabilitation, 34(2), 136-140. doi: 10.1111/j.13652842.2006.01682.x

[15] Fushima, K., Kitamura, Y., Mita, H., Sato, S., Suzuki, Y., \& Kim, Y. (1996). Significance of the cant of the posterior occlusal plane in Class II division 1 malocclusions. The European Journal of Orthodontics, 18(1), 27-40. doi: 10.1093/ejo/18.1.27

[16] Golovko, N. V. (2003). Orthodontics. Bite development, diagnosis of dental anomalies, orthodontic diagnosis. Poltava: PF "Forpika". 
[17] Gunas, I. V., Dmitriev, M. O., Tikholaz, V. O., ShinkarukDykovytska, M. M., Pastukhova, V. A., Melnik, M. P., \& Rudiy, Yu. I. (2018). Determination of normal cephalometric parameters by J. McNamara method for Ukrainian boys and girls. World of Medicine and Biology, 1(63), 19-22. doi: 10.26724/2079-8334-2018-1-63-19-22

[18] Gunas, I. V., Dmitriev, M. O., Prokopenko, S. V., ShinkarukDykovytska, M. M., \& Yeroshenko, G. A. (2017). Determination regulatory cephalometric options by the method of Tweed International Foundation for Ukrainian boys and girls. World of Medicine and Biology, 4(62), 27-31. doi: 10.26724/2079-83342017-4-62-27-31

[19] Holdaway, R. A. (1984). A soft-tissue cephalometric analysis and its use in orthodontic treatment planning. Part II. Am. J. Orthod., 85, 279-293. doi: https://doi.org/10.1016/00029416(84)90185-4

[20] Jayachandran, S., Ramachandran, C. R., \& Varghese, R. (2008). Occlusal Plane Orientation: A Statistical and Clinical Analysis in Different Clinical Situations. Journal of Prosthodontics, 17(7), 572-575. doi: 10.1111/j.1532849x.2008.00341.x

[21] Khvatova, V. A. (2005). Clinical Gnathology. M.: OOO "Publisher "Medicine".

[22] Lamarque, S. (1995). The importance of occlusal plane control during orthodontic mechanotherapy. American Journal of Orthodontics and Dentofacial Orthopedics, 107(5), 548-558.

[23] McNamara, J. A. Jr. (1984). Amethod of cephalometric evaluation. Am. J. Orthod., 86(6), 449-469. PMID: 6594933

[24] Quran, F. A. M. A., Hazza'a, A., \& Nahass, N. A. (2010). The Position of the Occlusal Plane in Natural and Artificial Dentitions as Related to Other Craniofacial Planes. Journal of Prosthodontics, 19(8), 601-605. doi: 10.1111/j.1532849x.2010.00643.x
[25] Rosati, R., Rossetti, A., De Menezes, M., Ferrario, V. F., \& Sforza, C. (2012). The occlusal plane in the facial context: inter-operator repeatability of a new three-dimensional method. International Journal of Oral Science, 4(1), 34-37. doi: 10.1038/ijos.2012.2

[26] Sahoo, S., Singh, D., Raghav, D., Singh, G., Sarin, A., \& Kumar, P. (2014). Systematic assessment of the various controversies, difficulties, and current trends in the reestablishment of lost occlusal planes in edentulous patients. Annals of medical and health sciences research, 4(3), 313319.

[27] Sato, M., Motoyoshi, M., Hirabayashi, M., Hosoi, K., Mitsui, N., \& Shimizu, N. (2006). Inclination of the occlusal plane is associated with the direction of the masticatory movement path. The European Journal of Orthodontics, 29(1), 21-25. doi: $10.1093 /$ ejo/cjl036

[28] Schmuth, G. P. F. (1971). Methodische Schwierigkeiten bei der Anwendung der Rontgenkephalometrie in der Kieferorthopadie. Fortschritte der Kieferorthopadie, 32(2), 317325.

[29] Schwarz, A. M. (1960). Roontgenostatics; practical evaluation of the tele-X-ray-photo. Publisher: Brooklyn, N.Y.: Leo L. Bruder.

[30] Slavicek, R. (2011). Relationship between occlusion and temporomandibular disorders: Implications for the gnathologist. American Journal of Orthodontics and Dentofacial Orthopedics, 139(1), 10-16. doi: 10.1016/j.ajodo.2010.11.011

[31] Steiner, C. C. (1959). Cephalometrics in clinical practice. Angle Orthod., 29, 8-29.

[32] Tweed, C. H. (1954). The Frankfort-Mandibular Incisor Angle (FMIA) in Orthodontic Diagnosis, Treatment Planning and Prognosis. Angle Orthod., 3, 121-169.

[33] Zhulev, E. N. (1995). Fixed prostheses: Theory, clinic and laboratory equipment. N. Novgorod: Publisher NGMD.

\section{ВИЗНАЧЕННЯ ІНДИВІДУАЛЬНИХ ТЕЛЕРЕНТГЕНОГРАФІЧНИХ ХАРАКТЕРИСТИК ПОЛОЖЕННЯ ЗМИКАЛЬНОЇ ПЛОЩИНИ У УКРАЇНСЬКИХ ЮНАКІВ І ДІВЧАТ ІЗ ОРТОГНАТИЧНИМ ПРИКУСОМ}

\section{Дмітрісв М. О., Гунас І. В., Дзевульська І. В., Жулкевич І. В.}

На сьогоднішній день немає чітких рекомендацій щодо застосування того чи іншого показника, цефалометричного методу, нормативної бази для мешканців України при оцінці цефалометричних характеристик змикальної площини. Мета дослідження - шляхом вивчення цефралометричних показників і проведення прямого покрокового регресійного аналізу розробити у юнаків і дівчат України з ортогнатичним прикусом математичні моделі індивідуальних характеристик положення змикальної площини. У 38 юнаків (віком від 17 до 21 року) та 55 дівчат (віком від 16 до 20 років) з оклюзією наближеною до ортогнатичного прикусу та збалансованими обличчями були отримані бокові телерентгенограми за допомогою пристрою Vеraviеwеросs 3D,


точки та вимірювання проводили заідно рекомендацій W. B. Downs, J. McNamara, R. A. Holdway, P. F. Schmuth, A. M. Schwarz, C. C. Steiner ma C. H. Tweed. В ліцензійному статистичному пакеті "Statistica 6.0", з використанням регресійного аналізу, проведено моделювання наступних телерентгенографічних характеристик положення змикальної площини: кута YGOCLPI, кута POR_DOP, кута POR_OCP та кута SN_OCP. Встановлено, що як в юнаків, так і у дівчат побудовані усі 4 можливих моделі з коефіцієнтом детермінації від 0,808 до 0,998 в юнаків і від 0,832 до 0,974 у дівчат. При аналізі моделей телерентаенографічних характеристик положення змикальної площини в залежності від особливостей метричних характеристик краніофаціального комплексу встановлено, що в юнаків найбільш часто до регресійних рівнянь входять показник Wits (21,1\% - до усіх 4 рівнянь), куm AB_NPOG (15,8\%) та відстань PN_POG (10,5\%). У дівчат найбільш часто до регресійних рівнянь входять - показник Wits (17,4\% - також до усіх 4 рівнянь); кут AB_NPOG, відстань AFH, куm MM та куm SN_GoGn (по 8,7\%). Таким чином, за допомогою методу покрокової регресії з включенням, у українців юнацького віку, на основі особливостей телерентгенографічних показників розроблені достовірні моделі індивідуальних телерентгенографрічних характеристик положення змикальної площини.

Ключові слова: змикальна площина, цефалометрія, регресійний аналіз, юнаки, дівчата, ортогнатичний прикус.

ОПРЕДЕЛЕНИЕ ИНДИВИДУАЛЬНЫХ ТЕЛЕРЕНТГЕНОГРАФИЧЕСКИХ ХАРАКТЕРИСТИК ПОЛОЖЕНИЯ ОККЛЮЗИОННОЙ ПЛОСКОСТИ У УКРАИНСКИХ ЮНОШЕЙ И ДЕВУШЕК С ОРТОГНАТИЧЕСКИМ ПРИКУСОМ

Дмитриев Н. А., Гунас И. В., Дзевульская И. В., Жулкевич И. В.

На сегодняшний день нет четких рекомендаций по применению того или иного показателя, цефалометрического метода, нормативной базы для жителей Украины при оценке цефалометрических характеристик замыкательной плоскости. Цель 
исследования - путем изучения цефалометрических показателей и проведения прямого пошагового регрессионного анализа разработать у юношей и девушек Украины с ортогнатическим прикусом математические модели индивидуальных характеристик положения замыкательной плоскости. У 38 юношей (в возрасте от 17 до 21 года) и 55 девушек (в возрасте om 16 до 20 лет) с окклюзией приближенной к ортогнатическому прикусу и сбалансированными лицами были получены боковые телерентгенограммы с помощью устройства Veraviewepocs 3D, Морита (Япония). Цефалометрический анализ

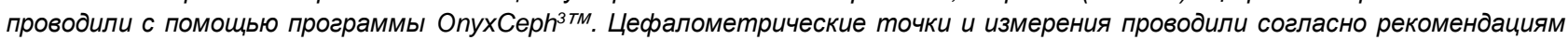
W. B. Downs, J. McNamara, R. A. Holdway, P. F. Schmuth, A. M. Schwarz, C. C. Steiner и C. H. Тwеed. В лицензионном статистическом пакете "Statistica 6.0", c использованием регрессионного анализа, проведено моделирование следующих телерентаенографических характеристик положения замыкательной плоскости: угла YGOCLPI, угла POR_DOP, угла POR_OCP и угла SN_OCP. Установлено, что как у юношей, так и у девушек построены все 4 возможных модели с коэфрфициентом детерминации от 0,808 до 0,998 у юношей и от 0,832 до 0,974 у девушек. При анализе моделей телерентгенографических характеристик положения замыкательной плоскости в зависимости от особенностей метрических характеристик краниофрациального комплекса установлено, что у юношей наиболее часто к регрессионным уравнениям входят - показатель Wits (21,1\% - к всем 4 уравнениям), угол AB_NPOG (15,8\%) u paccmoяние PN_POG (10,5\%). У девушек наиболее часто к регрессионным уравнениям входят - показатель Wits (17,4\% - также ко всем 4 уравнениям); угол $A B \_N P O G$, расстояние AFH, угол MM и угол SN_GoGn (по 8,7\%). Таким образом, с помощью метода пошаговой регрессии с включениями, для украинцев юношеского возраста, на основе особенностей телерентгенографических показателей, разработаны достоверные модели индивидуальных телерентгенографических характеристик положения окклюзионной плоскости.

Ключевые слова: окклюзионная плоскость, цефралометрия, регрессионный анализ, юноши, девушки, ортогнатический прикус. 